\title{
The Natural Durability and Drying Properties of Ganitri Wood (Elaeocarpus sphaericus Schum)
}

\author{
Trisna Priadi and Arizal Sani
}

\begin{abstract}
Ganitri (Elaeocarpus sphaericus Schum.) is a fast-growing species that was majority planted in community-based forets in Java. This research aimed to evaluate the natural durability and drying properties of ganitri wood, hence the best uses of the wood can be achieved. The wood durability was tested in laboratory and field scales based on SNI 7207:2014 and ASTM D 1758-02 standards respectively, while the wood treatibilty evaluation used soaking method with $5 \%$ borax preservative. The wood drying property was assessed through oven drying at $100^{\circ} \mathrm{C}$ temperature based on Terazawa method. The resistance of the wood against subterranean termites Coptotermes curvignathus is classified as durability class IV. Ganitri wood was very easy to be preserved with the cold soaking method. Boron retention in ganitri was $22.87 \mathrm{~kg}^{-3} \mathrm{~m}^{-3}$, while its penetration was $27.80 \mathrm{~mm}$ or $94.24 \%$. Ganitri had rather poor drying properties, which was prone to surface check. The proper drying for ganitri wood was suggested using initial and final temperatures $53^{\circ} \mathrm{C}$ and $83^{\circ} \mathrm{C}$, respectively, while the initial and final relative humidity were $85 \%$ and $30 \%$.
\end{abstract}

Keywords: drying, durability, fungi, ganitri wood, preservation, termite.

\section{Introduction}

The use of fast-growing wood species from community forests tends to increase. Meanwhile, optimal wood utilization requires a good understanding of wood properties. Many wood species from community forests are used as materials for buildings, furniture and other products. Ganitri is a fast-growing species that has been widely cultivated in several community forests in Java (Rohandi and Gunawan 2014). Ganitri (Elaeocarpus sphaericus Schum) is a tropical plant that grows and spreads from India, Nepal, Sri Lanka, Burma, Malaysia, and Indonesia. In Indonesia, ganitri trees can be found in the islands of Sumatra, Java, Kalimantan, Bali, Sulawesi and Nusa Tenggara. Ganitri can grow well from the coast to 1200 meters above sea level (Zuhud et al. 2013).

The seeds of ganitri are generally harvested and are well known as one of the non-wood forest products. Moreover, the wood of ganitri can be used as carpentry and building materials (Rohandi and Gunawan 2014). Ganitri wood has yellow heartwood and white sapwood, smooth texture, with straight and interlocked grain. The air-dry density of ganitri wood is 0.35 and is classified in strength class IV. The wood can be used as light construction, wooden tools, furniture, plywood, and panel products (Prihatini 2020). Furthermore, ganitri wood is easily preserved by the soaking method for up to 3 days so that the retention and penetration of boric acid equivalent (BAE) $10 \%$ met the requirements of the Indonesian National Standard (SNI) (Suhaendah and Siarudin 2015).

Some basic properties of ganitri wood have been studied as described above. However, there is insufficient scientific information on the natural durability and drying properties of ganitri wood, which are very important for proper processing and utilization to produce high-quality wood products. Therefore, the objective of this study was to evaluate the natural durability and drying properties of ganitri wood. Wood durability will determine the service life of wood products. Low durability wood will require preservation to protect from biodeterioration.

\section{Materials and Methods}

\section{Natural Durability}

The natural durability of ganitri wood (Elaeocarpus sphaericus Schum) against subterranean termites was tested in a laboratory scale based on SNI 7207:2014 standard (BSN 2014). Wood samples with the size of 2.5 $\mathrm{cm} \times 2.5 \mathrm{~cm} \times 0.5 \mathrm{~cm}$ were oven-dried at a temperature of $60 \pm 2^{\circ} \mathrm{C}$ for 48 hours to get the dry weight of the wood samples before testing $\left(\mathrm{W}_{1}\right)$.

A total of 200 grams of sterile sand was put into a test bottle, followed by adding $30 \mathrm{ml}$ of distilled water to regulate the water content of the sand. Then 200 subterranean termites (Coptotermes curvignathus Holmgren) from the worker caste were placed into the bottle. Furthermore, the test bottles were sealed using aluminum foil with some tiny holes for air circulation and kept in the dark for 4 weeks. For comparison in this study, jackfruit (Artocarpus heterophyllus) and sengon (Falcataria moluccana) woods represent durability class II and class IV wood, respectively. After four weeks of test, the wood samples were cleaned and then oven-dried at a temperature of $60 \pm 2^{\circ} \mathrm{C}$ for 48 hours to get wood sample weight after testing $\left(\mathrm{W}_{2}\right)$ and to calculate the weight loss of wood sample (Equation 1). The durability classifications against subterranean termites attack referred to the Indonesian National Standard 7207-2014 (Table 1). 
$W L=\frac{W_{1}-W_{2}}{W_{1}} \times 100$

where:

$\mathrm{WL}=$ Weight loss of wood sample $(\%)$

$\mathrm{W} 1=$ Wood weight before the test $(\mathrm{g})$

W2 $=$ Wood weight after the test $(\mathrm{g})$

Table 1. Durability classification of wood against subterranean termites

\begin{tabular}{ccc}
\hline Class & Durability & Weight Loss \\
\cline { 3 - 3 } I & Very Durable & $(\%)$ \\
II & Durable & $3.52 \sim 7.50$ \\
III & Moderate & $7.51 \sim 10.95$ \\
IV & Poor & $10.96 \sim 18.95$ \\
V & Very poor & $>18.95$ \\
\hline
\end{tabular}

Source: BSN 2014

Field test of wood durability based on ASTM D 175802. The size of the wood samples were $45.7 \mathrm{~cm} \times 2 \mathrm{~cm} \times 2$ $\mathrm{cm}$. The samples were oven-dried at $60^{\circ} \mathrm{C}$ for 48 hours before the test to determine the initial weight $\left(\mathrm{W}_{1}\right)$. After that, the 2/3 sample length were buried in the ground at Arboretum, Faculty of Forestry and Environment, IPB University. The inter-sample graves spacing was $30 \mathrm{~cm}$ within rows and $60 \mathrm{~cm}$ between rows. After 3 months of exposure, the sample woods were cleaned and oven dried again at $60^{\circ} \mathrm{C}$ for 48 hours to gain the final weight (W2) to calculate the wood weight loss. The wood damages due to termites and fungi were visually graded based on the criteria in Table 2 and Table 3.

Table 2. The assessment criteria of wood durability from termites attack

\begin{tabular}{|c|c|}
\hline $\begin{array}{c}\text { Durability } \\
\text { Grades }\end{array}$ & Attacks \\
\hline 10 & No attack; only 1 2 bites of termites \\
\hline 9 & Attack $\leq 3 \%$ across the sample \\
\hline 8 & $3 \%<$ attack $\leq 10 \%$ across the sample \\
\hline 7 & $10 \%<$ attack $\leq 30 \%$ across the sample \\
\hline 6 & $30 \%<$ attack $\leq 50 \%$ across the sample \\
\hline 4 & $50 \%<$ attack $\leq 70 \%$ across the sample \\
\hline 0 & Damage $>70 \%$ across the sample \\
\hline
\end{tabular}

Source: ASTM D 1758-02

Table 3. The assessment criteria of wood durability from fungal attack

\begin{tabular}{cl}
\hline $\begin{array}{c}\text { Durability } \\
\text { Grades }\end{array}$ & \multicolumn{1}{c}{ Attacks } \\
\hline 10 & No attack; only little fungal attack \\
9 & Attack $\leq 3 \%$ across the sample \\
8 & $3 \%<$ attack $\leq 10 \%$ across the sample \\
7 & $10 \%<$ attack $\leq 30 \%$ across the sample \\
6 & $30 \%<$ attack $\leq 50 \%$ across the sample \\
4 & $50 \%<$ attack $\leq 70 \%$ across the sample \\
0 & Damage $>70 \%$ across the sample \\
\hline
\end{tabular}

Source: ASTM D 1758-02

\section{Preservative Treatability}

The preservative treatability test used wood samples at the size of $10 \mathrm{~cm} \times 6 \mathrm{~cm} \times 6 \mathrm{~cm}$. The samples were airdried to get the moisture content below $16 \%$. Both ends of wood samples were coated with paraffin then weighed before treatment (W0). Then the wood samples were soaked in borax solution at a concentration of $5 \%$ for 48 hours. After preservation, the samples were weighed (W1) to determine the retention of borax in the samples using Equation 2.

$$
R=\frac{W_{1}-W_{0}}{V} \times C
$$

where:

$\mathrm{R}=$ Retention $\left(\mathrm{kg} \cdot \mathrm{m}^{-3}\right)$

$W_{0}=$ Wood weight before preservation $(\mathrm{kg})$

$W_{1}=$ Wood weight after preservation $(\mathrm{kg})$

$\mathrm{V}=$ Wood volume $\left(\mathrm{m}^{3}\right)$

C = Concentration of preservative solution (\%)

The wood samples were air-dried and cut into two pieces in the middle of the sample. The sample crosssections were sprayed with reagent $A$ and $B$ sequentially to determine boron penetration. Reagent $A$ consisted of $10 \mathrm{~g}$ of turmeric powder in $100 \mathrm{ml}$ of alcohol, while reagent $B$ contained $80 \mathrm{ml}$ of alcohol and $20 \mathrm{ml}$ of hydrochloric acid, which was saturated with salicylic acid. The color change to red indicated the presence of boron in the wood. Penetration measurements were performed in 2 ways. The penetration depth was directly measured at the penetrated cross-section from four sides and then averaged (Equation $3)$. The second penetration was calculated as the penetration percentage from the total cross-section area (Equation 4). The penetrated area was drawn on transparent plastic and overplayed on millimeter block paper for measuring the areas.

$$
\begin{aligned}
& \bar{X}=\frac{X_{1}+X_{2}+X_{3}+X_{4}}{4} \\
& \bar{X}=\frac{A_{p}}{A_{T}} \times 100
\end{aligned}
$$

where:

$\bar{X} \quad=$ Penetration $(\mathrm{mm}$ or $\%)$

$X_{1,2,3,4}=$ Penetration from four sides of sample

$A_{p} \quad=$ Penetrated area $\left(\mathrm{mm}^{2}\right)$

At $\quad=$ Total cross section area $\left(\mathrm{mm}^{2}\right)$

\section{Drying Properties}

The drying properties test of wood is based on Terazawa (1965) method. Wood sample size was $20 \mathrm{~cm} \times$ $10 \mathrm{~cm} \times 2.5 \mathrm{~cm}$ at fresh conditions (moisture content $>30 \%$ ) with 12 replication. The samples were dried at $100^{\circ} \mathrm{C}$ up to 
a constant oven-dried weight. Observation of defects (checks) was done every three hours. Deformation and internal check were evaluated at the end of drying. The samples were also weighed regularly. All the defects were measured and scored. The most severe defect score was used to determine the minimum and maximum temperatures and relative humidity for drying the wood (Table 4).

Table 4. Temperatures $(\mathrm{T})$ and relative humidity $(\mathrm{RH})$ in the initial and final drying (Terazawa 1965)

\begin{tabular}{|c|c|c|c|c|c|c|c|c|}
\hline \multirow{2}{*}{ Defects } & \multirow{2}{*}{$\begin{array}{l}\mathrm{T}\left({ }^{\circ} \mathrm{C}\right) \\
\text { and } \mathrm{RH} \\
(\%) \\
(\%)\end{array}$} & \multicolumn{7}{|c|}{ Defect Score } \\
\hline & & 1 & 2 & 3 & 4 & 5 & 6 & 7 \\
\hline \multirow{4}{*}{$\begin{array}{l}\text { Surface } \\
\text { check }\end{array}$} & Initial T & 70 & 65 & 55 & 55 & 53 & 50 & 45 \\
\hline & Initial RH & 75 & 78 & 82 & 83 & 85 & 90 & 90 \\
\hline & Final $\mathrm{T}$ & 95 & 90 & 85 & 83 & 82 & 81 & 79 \\
\hline & Final $\mathrm{RH}$ & 29 & 29 & 27 & 30 & 30 & 28 & 28 \\
\hline \multirow{4}{*}{$\begin{array}{c}\text { Deforma } \\
\text { tion }\end{array}$} & Initial T & 70 & 66 & 58 & 54 & 50 & 49 & 47 \\
\hline & Initial RH & 75 & 75 & 78 & 81 & 81 & 85 & 89 \\
\hline & Final $T$ & 95 & 88 & 83 & 80 & 77 & 75 & 70 \\
\hline & Final $\mathrm{RH}$ & 29 & 29 & 25 & 27 & 28 & 27 & 27 \\
\hline \multirow{4}{*}{$\begin{array}{l}\text { Internal } \\
\text { Check }\end{array}$} & Initial T & 70 & 55 & 50 & 49 & 48 & 45 & \\
\hline & Initial RH & 75 & 81 & 81 & 85 & 85 & 89 & \\
\hline & Final $T$ & 95 & 83 & 77 & 73 & 71 & 70 & \\
\hline & Fnal RH & 29 & 27 & 25 & 27 & 27 & 27 & \\
\hline
\end{tabular}

\section{Data Analyses}

The durability, treatability and drying properties data of wood were analyzed descriptively. The effect of wood species on wood durability and treatability was analyzed using variance analysis (ANAVA) with a completely randomized experimental design and further Duncan multiple range tests when the ANAVA showed a significant effect at $95 \%$ confidence interval.

\section{Results and Discussion}

\section{The Natural Durability of Ganitri Wood}

Based on four months of laboratory testing, ganitri wood was attacked by subterranean termites, as well as jackfruit and sengon woods. The weight loss of woods due to termites' attacks is shown in Figure 1.

Figure 1 shows that the weight loss of ganitri wood was slightly lower than sengon but much higher than jackfruit samples, which indicated that ganitri wood is more durable than wood sengon but less durable than jackfruit wood. Pandit and Kurniawan (2008) stated that the natural durability of wood sengon is classified into durable class $\mathrm{IV} \sim \mathrm{V}$, so sengon is prone to subterranean termites. Febrianto et al. (2013) stated that the natural durability of jackfruit from the termites belonged to class II, which means that the wood is resistant to the termites. According to
Morimoto et al. (2006), A. heterophyllus wood contained artocarpin that had a fatal effect against Reticulitermes speratus termites. In addition, Saiin (2017) reported that jackfruit wood extractives contained morine substance. It was alleged that this extractive substance was unfavorable to termites. Syafi'i (2001) also stated that extractive substances could cause woods to have high natural durability.

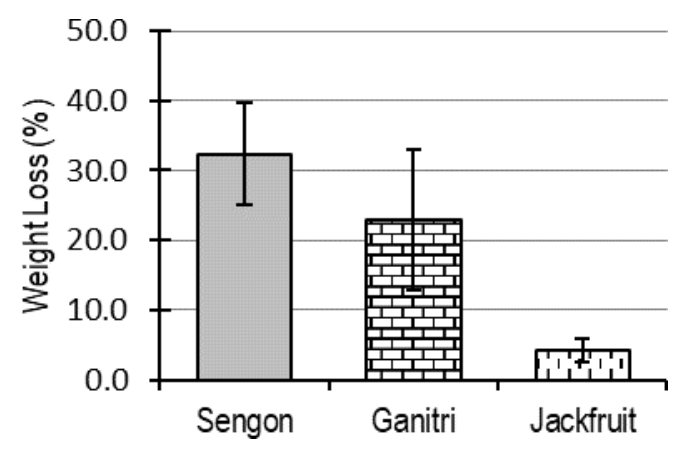

Figure 1. Weight loss of wood samples due to subterranean termites attack

The analysis of variance revealed that the wood species significantly affected the weight loss of the sample at a $95 \%$ confidence interval. In this lab experiment, the Duncan test showed that the weight loss of ganitri wood was not significantly different from that of sengon wood, but it was significantly higher than that of jackfruit wood. The higher the wood weight loss value, the lower wood durability from subterranean termites attack. Therefore, the resistance of sengon and ganitri woods against subterranean termites was relatively similar (class IV), but less resistant than that of jackfruit wood.

The durability field test shows that wood damage was mostly caused by subterranean termites' attacks, particularly Macrotermes gilvus (Figure 2). Besides, there were also some fungal attacks. Heavy damage occurred in ganitri and sengon woods due to termite attacks, while less damage occurred in jackfruit wood (Figure 3). The weight loss of ganitri wood was $86.4 \%$, while in sengon and jackfruit woods were $64.4 \%$ and $0.7 \%$, respectively.

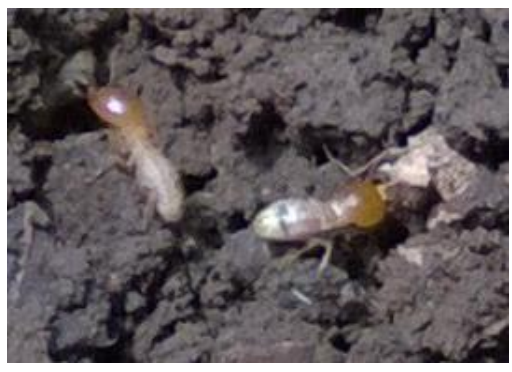

Figure 2. Subterranean termites (Macrotermes gilvus) were found on tested samples 


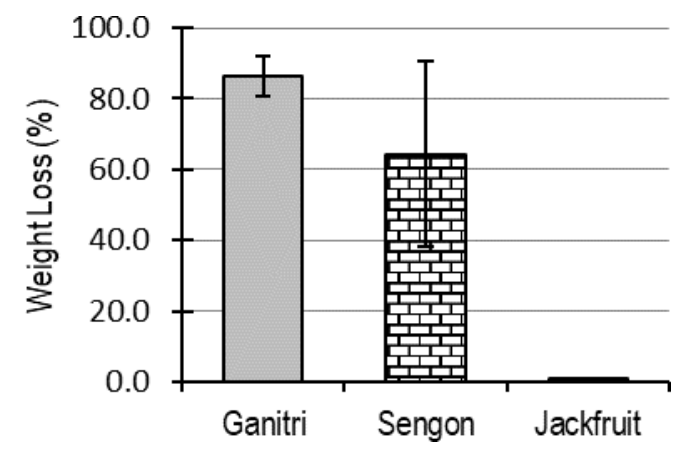

Figure 3. Weight loss of sample woods in the field test.

Figure 3 shows that the weight loss in the field test of ganitri wood was higher than that of sengon and jackfruit woods. This means that ganitri wood was less durable from biodeterioration in ground contact test than sengon and jackfruit woods. The ANAVA analysis revealed that wood species significantly affected the weight loss of wood samples at a $95 \%$ confidence interval. Moreover, the Duncan test resulted that the weight loss of ganitri wood was significantly higher than jackfruit wood but was not significantly different from that of sengon wood.

The visual grading of defects generally showed similar results to the weight loss variable. Ganitri wood had the lowest grade (Table 5), which indicated the lowest durability against termite and fungi. Jackfruit wood was more durable than sengon wood. In the field ground contact test, the sample woods were influenced by daily wet (rain) and dry that support the biodeterioration process by termites and fungi. Nuriyatin et al. (2003) reported that the characteristics of different woods affect the behavior of termites when they contact or bite the wood as a nutrient source. Wood containing toxic extractive substances can prevent termite and fungal attacks. Termites will choose the most favorable wood for their food. This visual grading also showed that termite attack was more severe than fungal attack.

Table 5. Durability grade of woods from subterranean termites and fungi in the field test

\begin{tabular}{lcc}
\hline $\begin{array}{l}\text { Wood } \\
\text { Samples }\end{array}$ & $\begin{array}{c}\text { Durability Grade } \\
\text { against Termites }\end{array}$ & $\begin{array}{c}\text { Durability Grade } \\
\text { against Fungi }\end{array}$ \\
\hline Ganitri & 4 & 7 \\
Sengon & 6 & 9 \\
Jackfruit & 10 & 10 \\
\hline
\end{tabular}

Comparing the durability in lab and field tests shows that ganitri wood was more prone to biodeterioration in the field than that of sengon. However, in lab tests, ganitri wood was more resistant to termite than sengon wood. It reveals that when ganitri wood is influenced by environmental wetting and attack by fungi, it is more favorable to termite attack.

\section{The Preservative Treatability}

The retention of borax preservative in ganitri wood was $22.9 \mathrm{~kg} \cdot \mathrm{m}^{-3}$, while the preservative penetration was $27.8 \mathrm{~mm}$ (Table 6). Both retention and penetration of preservatives in this research fulfilled Indonesian National Standard (SNI 03-5010.1-1999). According to this SNI standard, preservative retention for indoor and outdoor are $8.0 \mathrm{~kg} \cdot \mathrm{m}^{-3}$ and $11.0 \mathrm{~kg} \cdot \mathrm{m}^{-3}$, respectively, while the penetration must be more than $5 \mathrm{~mm}$ (BSN 1999).

The penetration of borax preservative into ganitri wood was about $94.2 \%$ (Table 6). It revealed that based on the classification of IUFRO in Smith and Tamblyn (1970), the treatability of ganitri wood was easy. Therefore ganitri wood can be preserved with borax preservative by soaking method for 48 hours.

Table 6. Preservative treatability of ganitri wood

\begin{tabular}{|c|c|c|c|}
\hline $\begin{array}{c}\text { Testing } \\
\text { Variables }\end{array}$ & $\begin{array}{l}\text { Testing } \\
\text { Values }\end{array}$ & $\begin{array}{l}\text { Standar } \\
\text { Values }\end{array}$ & Notes \\
\hline $\begin{array}{l}\text { Retention } \\
\left(\mathrm{kg} \cdot \mathrm{m}^{-3}\right)\end{array}$ & 22.9 & $\begin{array}{c}8 \text { (indoor) } \\
11 \text { (outdoor) }\end{array}$ & $\begin{array}{l}\text { SNI 03-5010.1-1999 } \\
\text { SNI 03-5010.1-1999 }\end{array}$ \\
\hline $\begin{array}{l}\text { Penetration } \\
(\mathrm{mm})\end{array}$ & 27.8 & 5 & SNI 03-5010.1-1999 \\
\hline $\begin{array}{l}\text { Penetration } \\
(\%)\end{array}$ & 94.2 & > 90 (easy) & $\begin{array}{l}\text { IUFRO method (Smith } \\
\text { and Tamblyn 1970) }\end{array}$ \\
\hline
\end{tabular}

\section{The Drying Properties}

The drying test results in that ganitri wood had fairly poor drying properties (Table 7). This wood was prone to surface check with a score of 5 . The surface check mainly occurred at the beginning of the drying process when the moisture content of wood is still high. According to Yamashita et al. (2013), a wood surface check is generally caused by dimensional changes that are not the same in all wood parts. The surface of wood dries up faster, but the wood inside is still saturated with water. Checks generally occur on parenchyma rays in the wood because they are the weakest part of the wood structure. According to Rasmussen (1961), surface checks frequently occur in the rays, resin canals, and mineral layers. The way to avoid this defect is by providing high air humidity at the beginning of the drying process, and the temperature should not be too high (Walker 2007).

Table 7. Drying defects evaluation of ganitri wood

\begin{tabular}{cccccccc}
\hline \multicolumn{2}{c}{$\begin{array}{c}\text { Surface } \\
\text { Checks }\end{array}$} & \multicolumn{2}{c}{$\begin{array}{c}\text { Internal } \\
\text { Checks }\end{array}$} & \multicolumn{2}{c}{ Deformation } & $\begin{array}{c}\text { Max. } \\
\text { Score }\end{array}$ & $\begin{array}{c}\text { Drying } \\
\text { Prop. }\end{array}$ \\
\hline $\max$ & $\min$ & $\max$ & $\min$ & $\max$ & $\min$ & & \\
5 & 1 & 1 & 1 & 1 & 1 & 5 & $\begin{array}{c}\text { Fairly } \\
\text { Poor }\end{array}$ \\
\hline
\end{tabular}


The worst defect that occurred in ganitri wood was surface checks with a score of 5 (Table 7). Therefore it suggested drying temperature was $53 \sim 82^{\circ} \mathrm{C}$, while the relative humidity (RH) was $85 \% \sim 30 \%$ (Table 8 ).

Table 8. The drying temperatures and relative humidity (RH) for ganitri wood

\begin{tabular}{|c|c|c|c|c|}
\hline \multirow[b]{2}{*}{ Wood } & \multicolumn{2}{|c|}{ Temperatures $\left({ }^{\circ} \mathrm{C}\right)$} & \multicolumn{2}{|c|}{$\mathrm{RH}(\%)$} \\
\hline & Initial & Final & Initial & Final \\
\hline Ganitri & 53 & 82 & 85 & 30 \\
\hline
\end{tabular}

The durability of ganitri wood from subterranean termite is about the same as sengon wood, class IV. Ganitri wood can be easily preserved with borax preservatives. Its retention was $22.9 \mathrm{~kg} \cdot \mathrm{m}^{-3}$, while the penetration was 27.8 $\mathrm{mm}$ or $94.2 \%$. The drying property of ganitri wood is fairly bad. The suggested drying for this wood is using temperature $53 \sim 82{ }^{\circ} \mathrm{C}$ and relative humidity $85 \sim 30 \%$.

\section{References}

[ASTM] American Society for Testing and Materials. 2002. Test Method of Evaluating Wood Preservatives by Field Test with Stakes. ASTM D 1758-02.

[BSN] Badan Standardisasi Nasional.1999. Pengawetan Kayu untuk Perumahan dan Gedung. SNI 03-5010.11999

[BSN] Badan Standardisasi Nasional. 2014. Uji Ketahanan Kayu Terhadap Organisme Perusak Kayu. SNI 72072014.

Febrianto, F.; Pranata, A.Z.; Arinana; Gumilang, A. 2013. Keawetan alami sembilan jenis kayu dari kampus dramaga Institut Pertanian Bogor terhadap serangan rayap. JITKT. 11 (1): 19-28.

Morimoto, M.; Ohta, Y.; Ihara, T.; Arima, K.; Fukumoto, H.; Chavasiri, W.; Komai, K. 2006. Insect antifeedants in Thailand plant extracts against the common cutworm, Spodoptera litura, and a subterranean termite, Reticulitermes speratus. Jpn. J. Environ. Entomol. Zool. 17(1):1-7. https://www.jstage.jst.go.jp/article/jjeez/17/1/17_1/_arti cle/-char/ja/

Nuriyatin, N.; Apriyanto, E.; Satriya, N.; Saprinurdin. 2003. Ketahanan lima jenis kayu berdasarkan posisi kayu di pohon terhadap serangan rayap. JIPI. 5 (2): 77-82.

Prihatini, E.; Maddu, A.; Rahayu, I. S.; Kurniati, M. 2020. Sifat Dasar Kayu Ganitri (Elaeocarpus sphaericus (Gaertn.) K. Schum.) dari Sukabumi dan Potensi
Penggunaannya. Jurnal IImu Kehutanan. 14(1): 109118.

https://doi.org/10.22146/jik.57480.

Rasmussen, E.F. 1961. Dry Kiln Operator's Manual. The US. Departement of Agricultural. Agric.

Rohandi, A.; Gunawan. 2014. Sebaran Populasi dan Potensi Tanaman Ganitri (Elaeocarpus ganitrus Roxb) di Jawa Tengah. Jurnal IImu Kehutanan. 8(1):25-33.

Saiin, C. 2017. Isolation of morin from the wood of Thai Artocarpus heterophyllus. Asian Journal of Natural \& Applied Sciences. 6(4): 85-89.Smith, D.N.R.; Tamblyn, N. 1970. Proposed Scheme for An International Standard Test for The Resistance of Timbers to Impregnation With Preservatives. New Zealand (AU): Forest Product Research Laboratory. https://doi.org/10.22146/jik.8550.

Suhaendah, E.; Siarudin, M. 2015. Pengawetan Kayu Ganitri dan Mahoni melalui Rendaman Dingin dengan Bahan Pengawet Boric Acid Equivalent. Jurnal IImu dan Teknologi Kayu Tropis. Journal of Tropical Wood Science and technology. 13(2):185-192. https://doi.org/10.51850/jitkt.v13i2.34

Syafi'i, W. 2001. Eksplorasi dan Identifikasi Komponen BioAktif Beberapa Jenis Kayu Tropis dan Kemungkinan Pemanfaatannya Sebagai Bahan Pengawet Kayu Alami. Bogor (ID). Institut Pertanian BogorTerazawa, S.1965. An easy method for the determination of the wood drying schedule. Wood Industry. Wood Technological Association of Japan. 20 (5): 216-226.

Pandit, I.K.N.; Kurniawan, D. 2008. Anatomi Kayu: Struktur Kayu, Kayu sebagai Bahan Baku dan Ciri Diagnostik Kayu Perdagangan Indonesia. Bogor (ID). Institut Pertanian Bogor

Walker, J.C.F. 2006. Primary Wood Processing: Principles and Practice $2^{\text {nd }}$ ed. London (GB): Springer.

Yamashita, K.; Hirakawa, Y.; Saito, S.; Nakatani, H.; Ikeda, M.; Ohta, M. 2013. Effect of cross-sectional dimensions on bow and surface checking of sugi (Cryptomeria japonica) boxed-heart square timber dried by conventional kiln drying. J Jap Wood Res Soc. 60 (1): 1-11.

Zuhud, E.A.M.; Siswoyo, E.; Sandra, E.; Hikmat, A.; Adhiyanto, E. 2013. Buku Acuan Umum Tumbuhan Obat Indonesia Jilid VII. Jakarta (ID): Dian Rakyat.

Trisna Priadi and Arizal Sani

Department of Forest Products, Faculty of Forestry,

IPB University, Bogor, Indonesia

Tel. : 087770097565

E-mail: trisnapriadiipb@yahoo.com

ORCID ID: https://orcid.org/0000-0003-0776-7776 